\title{
圭目縫い絞りの柄の評価
}

\author{
岐皁大学工学部 内田 貴・岡村政明
}

\section{Evaluation of a Mokumenui-shibori Pattern}

\author{
Takashi Uchida ${ }^{* 1}$ and Masaaki Okamura $^{* 1}$
}

\author{
${ }^{* 1}$ Faculty of Engineering, Gifu University, Yanagido 1-1, Gifu 501-1193, Japan
}

\begin{abstract}
In consequence of our previous study revealed the appearance mechanism of a Mokumenui-shibori pattern. Also a simulation program which generates an image of shibori pattern by stitch lengths was developed.

The purpose of this study is to establish an objective evaluation of a Mokumenui-shibori pattern.

First, in regard to feature extractions of textures, we evaluated two types of Mokumenui-shibori patterns which were created by the simulation program using two types of artificial stitch lengths. One type of artificial stitch lengths had a different standard deviation on stitch lengths, and other type had a peak value in a distribution of stitch lengths. To evaluate two types of patterns, there were three kinds of approaches for feature extractions of textures. One was simply to count the number of a pattern separated and a pattern interrupted in each. Others were to calculate a standard deviation of marginal distribution and a two dimensional power spectrum. Additionally, we calculated a fractal dimensions for evaluation.

Then we evaluated some real pattern of Mokumenui-shibori which was simulated by actual stitch lengths.

As a result of this study, in comparison with amateurs, there was indicated that patterns by professionals were fine and complicated with directivity kept.
\end{abstract}

(Received 4 April, 2008 ; Accepted 29 October, 2008)

\section{1. 緒 言}

これまでの報告で, 圭目縫い絞りの柄の発現を左右す る針目の間隔を検討し, 伝統的な職人の技と素人との違 いを明確にした[1]。また，柄の発現における針目と柄の 関係を明らかにし, 針目位置から圭目縫い絞りの柄をシ ミュレーションする方法を確立した[2].

しかしながら, 絞り柄のような複雑で捉え所のない模 様についての評価は, 図案や意匠構成, 風合いなどに対 する抽象的, 感覚的な表現による定性的評価しかなされ ていない[3].

本研究では, 圭目縫い絞りの柄の定量的な評価を行う ため, 画像処理の手法を用いた柄の客観的評価を行うこ とを目的とした。

圭目縫い絞りの柄を画像として扱うことで, 画像の特 徵抽出の手法が適用でき, 柄の定量的な評価に応用でき ると考えた。はじめに，人工的に作成した針目間隔を用 いてシミュレーション・プログラムで柄を作成し，それ らのテクスチャおよびフラクタルに関する評価を行った。 ついで, 実際の絞り柄について同様の評価を行い, 熟練 者と素人の柄の違いを明らかにした。

\section{2. 評価する柄の準備}

圭目縫い絞りは，白布を平縫いした後に糸を引き締め， 染色を行うと縦方向に圭目状のすじが現れる絞り技法で, 柄は引き締めた時に生じるひだが染色されて発現する. このときひだの先端が強く染色され，ひだの内側部分は 浸透が難しくぼけた染色となる.

圭目縫い絞りの柄は, ひだの先端が強く染色されるこ とで特徵付けられ，ひだは平縫い時の針目間隔によって 形が決まる.これまでの研究[1]で, 針目間隔が正規分布 で近似でき平均值がほぼ等しく分布の幅が異なるものと, 正規分布での近似がむずかしくピークの位置が異なるも のがみられた。そこで, 次の 2 種類の針目間隔の場合に ついて柄を評価した。

1）試料全体の針目間隔の平均は等しく, 標準偏差の異 なる正規分布を与えた場合

2）試料全体の針目間隔に $1 \mathrm{~mm}$ から $5 \mathrm{~mm}$ の間でピーク を持たせた三角分布を与えた場合

ここで評価には，パソコンによって正規分布および三 角分布を与えた針目間隔を生成し，シミュレーション・ 
プログラムにより予測した各 10 枚の柄を用いた.

なお，正規分布を与えた場合，三角分布を与えた場合 ともに, 生成される針目間隔の最小值は $1 \mathrm{~mm}$, 最大值は $5 \mathrm{~mm}$ とし，1行あたりの針目数は，各行における針目間 隔の合計が針目行の長さに達するまでとした。

\section{1 正規分布を与えた場合}

これまでの報告[1]から，圭目縫い絞りの針目間隔の平 均は概ね $3 \mathrm{~mm}$ である. 針目行を 10 行, 1 行あたりの針目 行の長さを $150 \mathrm{~mm}$, 針目間隔の平均值を $3 \mathrm{~mm}$ とし, 標 準偏差 $(\mathrm{SD})$ が $0.3,0.45,0.6,0.75$ および 1.0 となる正規 分布を針目間隔に与えて試料とした. Fig.1(a)から (e)に それぞれの標準偏差におけるシミュレーション結果の一 例を示す。

\section{2 三角分布を与えた場合}

正規分布の場合と同様に, 針目行を 10 行, 1 行あたり の長さを $150 \mathrm{~mm}$ とし, 針目間隔のピーク $(\mathrm{P})$ が $1 \mathrm{~mm}, 2 \mathrm{~mm}$, $3 \mathrm{~mm}, 4 \mathrm{~mm}$ および $5 \mathrm{~mm}$ となるような三角分布を針目間 隔に与えて試料とした. Fig.1 (f) から (j)にシミュレーショ ン結果の一例を示す.

\section{3. 柄の評価}

はじめに, 圭目縫い絞り特有の柄の分岐および途切れ について検討した.

ついで, 圭目縫い絞りの柄は染色部分と非染色部分か らなる色の濃淡で表現されるため, 柄の定量的な評価と して濃淡画像の解析方法を用いて検討した. 解析方法は テクスチャ解析の統計的方法として周辺分布, スペクト ル的方法としてパワースペクトル, またフラクタル解析 としてボックス次元をそれぞれ用いた。

なお, 周辺分布, パワースペクトルおよびボックス次 元を求めるために用いた画像は, 全て同じ画像解像度と し, 作成した画像の中央を無作為に $512 \times 512$ ピクセルに 切り取ったグレースケール画像(色階調 0〜255) とした.

\section{1 分岐数と途切れ数}

圭目縫い絞りの柄は引き締めた時に生じるひだが染色 されて発現する。このとき平縫い糸は布の表面と裏面を 交互に通過し，針の貫通穴を裏面から表面に貫通する『表 の針目』とその逆の『裏の針目』に分けると, 『表の針目』 -『裏の針目』間の『表の針目間隔』による縫い目と, 『裏 の針目』-『表の針目』間の『裏の針目間隔』による縫い 目が生じる．柄は『表の針目間隔』から作られる“表の柄” と,『竜の針目間隔』作られる“裏の柄”に分けることがで き，柄が交わることはない.

また，それぞれの針目行は独立して縫われるため，針 目間隔の違いや針目行毎の針目の数の違いにより，前後 の針目行でひだを形成できない場合が生じる。この状態 で糸を引き締め染色すると, Fig. 1 に見られる通り, 柄が 二方向に発現する分岐や, 柄が途中で中断される途切れ が生じる。

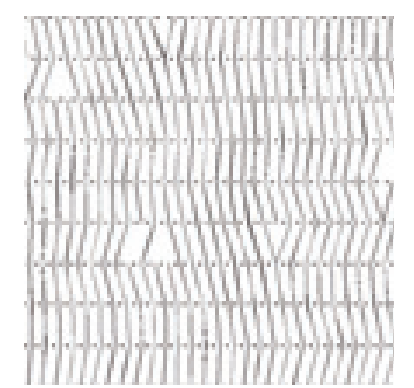

(a) $\mathrm{SD} 0.3$

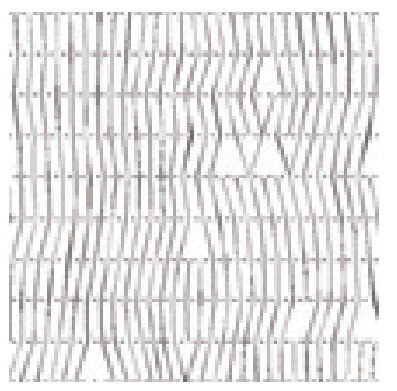

(b) $\mathrm{SD} 0.45$

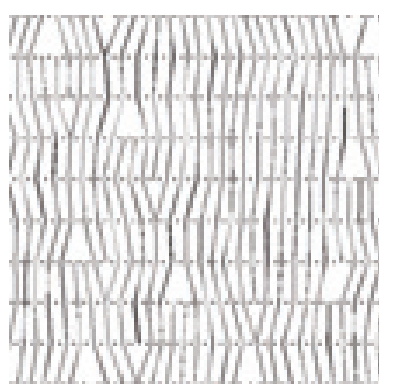

(c) SD 0.6

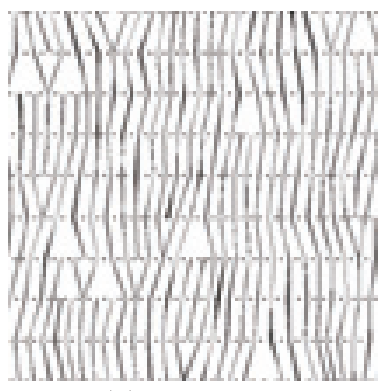

(d) $\mathrm{SD} 0.75$

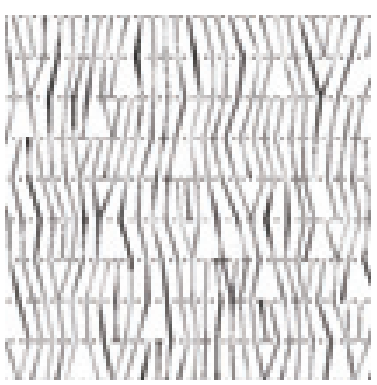

(e) SD 1.0

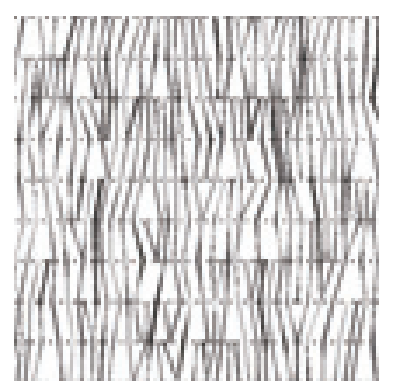

(f) $\mathrm{P} 1 \mathrm{~mm}$

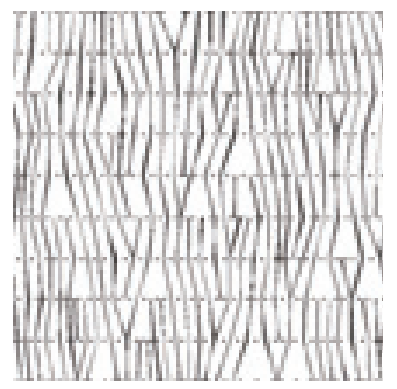

(g) $\mathrm{P} 2 \mathrm{~mm}$

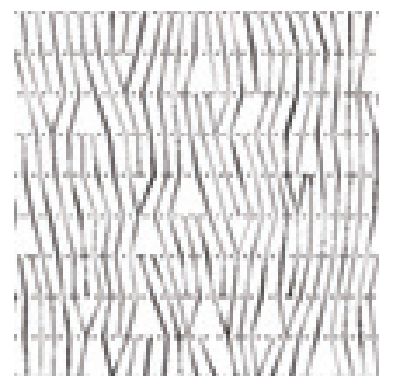

(h) $\mathrm{P} 3 \mathrm{~mm}$

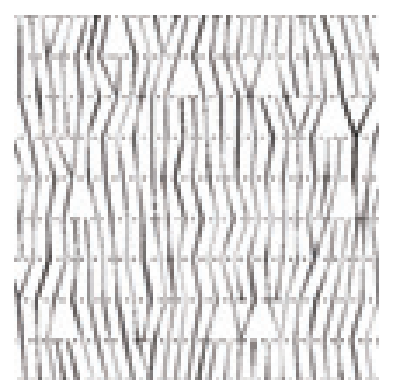

(i) $\mathrm{P} 4 \mathrm{~mm}$

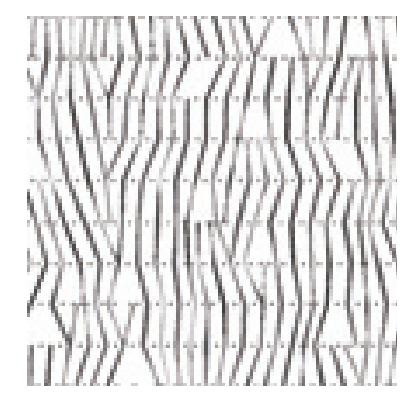

(j) $P 5 \mathrm{~mm}$
Fig. 1 Example images of simulation result in each condition.

分岐および途切れの数が多いほど柄の発現方向に変化 を生じ, 複雑な柄になると考えられ, これらの数をそれ ぞれ目視で数えた.

Fig. 2 に正規分布を与えた場合の針目間隔の標準偏差と 
+ Separated $\boldsymbol{\Delta}$ Separated [Ave.] $\times$ Interrupted $\bullet$ Interrupted [Ave.]

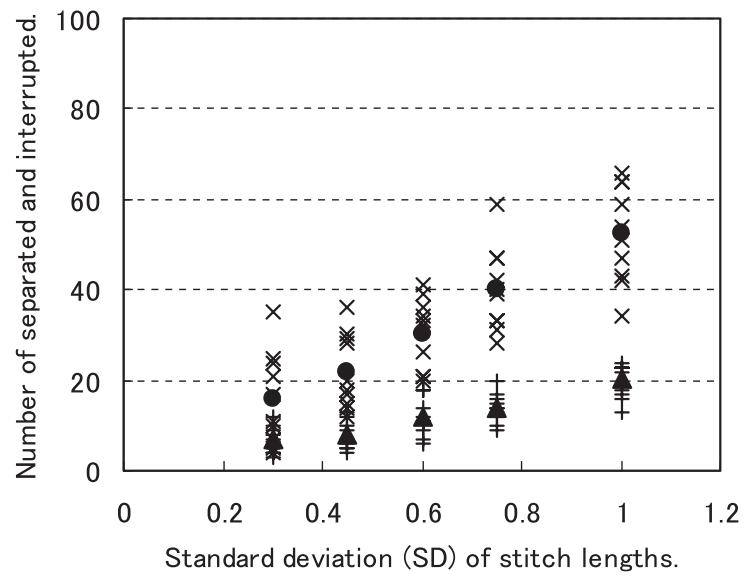

Fig. 2 Relationship between a standard deviation of stitch lengths and the number of a pattern separated and interrupted.

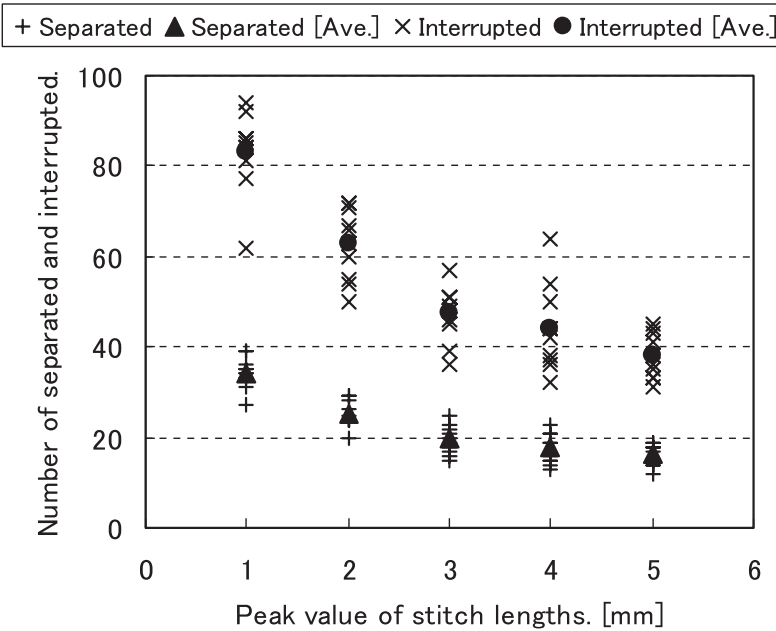

Fig. 3 Relationship between a peak value of stitch lengths and the number of a pattern separated and interrupted.

分岐数および途切れ数の関係を, Fig. 3 に三角分布を与え た場合のピーク值とそれぞれの数の関係を示す.

正規分布を与えた場合では, 針目間隔の標準偏差が大 きくなるにつれて分岐の数および途切れの数がほぼ直線 的に増加している。.三角分布を与えた場合では, ピーク 值が大きくなるにつれてそれぞれの数が反比例的に減少 している.

したがって，針目間隔に平均值の等しい正規分布を与 えた場合は，標準偏差が大きくなるにつれて柄は複雑に
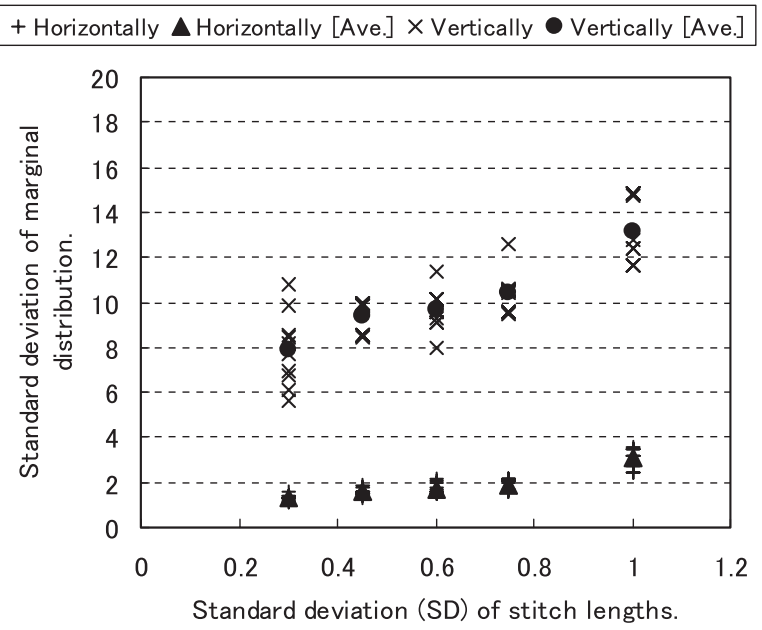

Fig. 4 Relationship between a standard deviation of stitch lengths and a standard deviation of a marginal distribution.

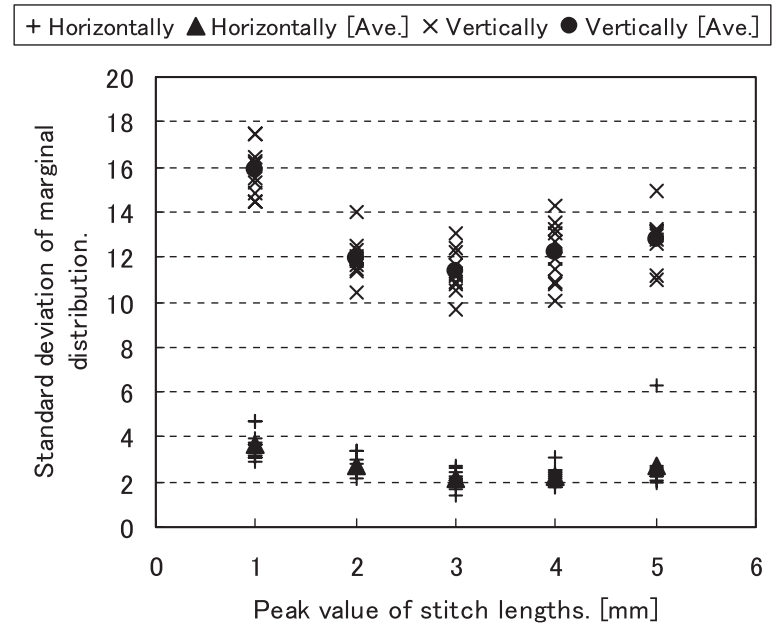

Fig. 5 Relationship between a peak value of stitch lengths and a standard deviation of a marginal distribution.

なり，また針目間隔に一定の範囲内でピークの異なる三 角分布を与えた場合は，ピーク值が小さいほど柄は複雑 になる。

\section{2 周辺分布}

圭目縫い絞りの柄は，平縫い方向に対して垂直方向に 発現する.しかしながら，柄の一つ一つに着目すると， 針目間隔の相対位置に起因して発現方向が左右に振れて いる.

周辺分布は，画像に対して水平方向と垂直方向に色階 調を積分することで画像の特徵を抽出する手法で, テク

Table 1 Average of gray scales in each condition.

\begin{tabular}{cccccccccccc}
\hline & \multicolumn{4}{c}{ Normal Distribution } & \multicolumn{4}{c}{ Peak Value } \\
\cline { 2 - 9 } & SD 0.3 & SD 0.45 & SD 0.6 & SD 0.75 & SD 1.0 & P 1 & P 2 & P 3 & P 4 & P 5 \\
\hline Average of Gray Scales & 18.8 & 20.3 & 22.2 & 24.0 & 27.2 & 35.3 & 27.1 & 25.2 & 26.7 & 29.4 \\
\hline
\end{tabular}


スチャの方向性などを定量化することができる [4]. 本研 究では, 各方向の色階調の標準偏差を求め柄の違いを検 討した。一方向の標準偏差が大きく他方向が小さい場合， 柄は標準偏差の大きい方への方向性があるといえる。ま た, 水平方向, 垂直方向共に色階調の標準偏差は, 一つ 一つの柄の左右への傾きや，分岐や途切れに影響される.

Fig. 4 に正規分布を与えた場合, Fig. 5 に三角分布を与 えた場合の周辺分布を示す。またTable 1 に各場合におけ る色階調の平均值を示す.

本研究で用いた画像は全て $512 \times 512$ ピクセルであるが, 画像サイズに依存しない定量化を行うため, 各ドット行 またはドット列の色階調の積分值に対する標準偏差を, 画像幅または高さで割り，ドット当りの值とした。また 通常の画像は, 黒色が色階調 0 , 白色が色階調 255 となる が, 本研究では白黒の色階調を反転させて積分值を算出 した.

いずれの場合も水平方向よりも垂直方向の值が大きく， 柄が主に垂直方向であることがわかる.

正規分布を与えた場合, 針目間隔の標準偏差が大きく なるにつれて, 周辺分布の水平方向, 垂直方向ともに色 階調の標準偏差が直線的に大きくなり，これは分岐数お よび途切れ数の傾向とも一致する. また, 色階調の平均 值も直線的に大きくなる.

一方, 三角分布を与えた場合, 各方向の周辺分布の色 階調の標準偏差はピーク值 $3 \mathrm{~mm}$ まで減少し, 分岐数およ び途切れ数の減少に一致する. また, ピーク值 $3 \mathrm{~mm}$ から $5 \mathrm{~mm}$ の間は標準偏差がわずかに増加する。これは針目間 隔が広くなり，柄の傾きが大きくなるためである．色階 調の平均值も標準偏差と同様の傾向を示す.

\section{3 パワースペクトル}

時間信号と同様に空間的に変化する信号に対しては, 空間周波数が定義され，スペクトルによって表現するこ とができる. 2 次元画像の濃淡を用いてスペクトル分布を 得るには, 1 次元離散フーリエ変換 $(\mathrm{DFT})$ を 2 次元に拡張 した 2 次元 DFTを用いる. 画像の持つ特有のスペクトル を解析することで, テクスチャの構成要素の大きさ (テク スチャの粗さ)や方向性などが判別できる [5].

Fig. 6(a)から (e)に正規分布を与えた場合, Fig. 6(f)か ら (j) に三角分布を与えた場合の代表的な 2 次元パワース ペクトルを示す.

2 次元パワースペクトルでは, 中心からの半径方向の広 がりを低周波から高周波の周波数分布で示し, 分布が示 す円弧方向が元画像のテクスチャの方向を示す。低周波 に偏った分布は粗い画像を示し, 高周波にまで広がった 分布は細かい画像を示す．またテクスチャの方向は, パ ワースペクトルで示される分布方向に直角となる.

正規分布を与えた場合の結果では，テクスチャの方向 性にあまり差が見られないが, 標準偏差が大きくなるに つれて低周波域での顕著な偏りが弱くなり，高周波域へ の広がりが強くなっている。したがって, 標準偏差を大

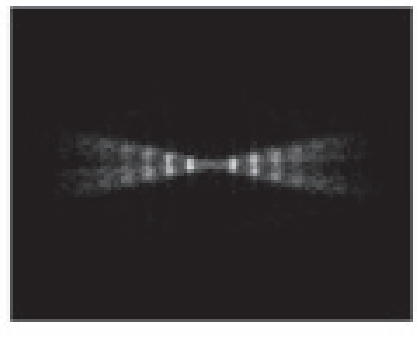

(a) $\mathrm{SD} 0.3$

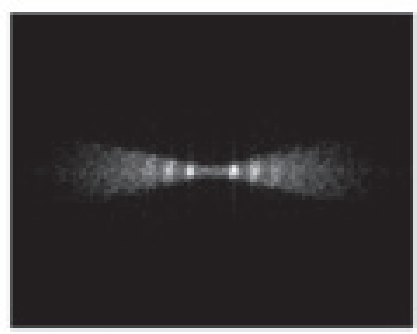

(b) SD 0.45

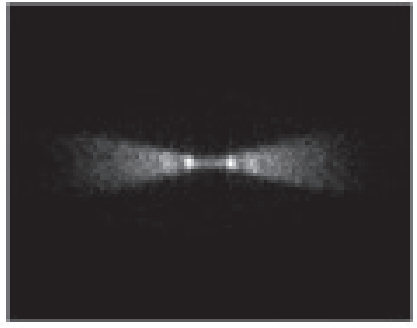

(c) $\mathrm{SD} 0.6$

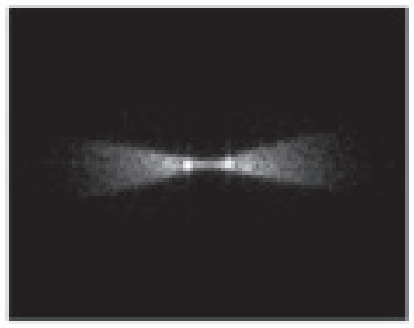

(d) SD 0.75

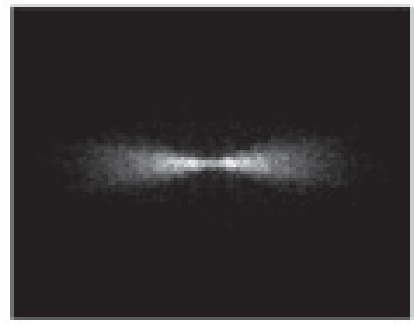

(e) SD 1.0

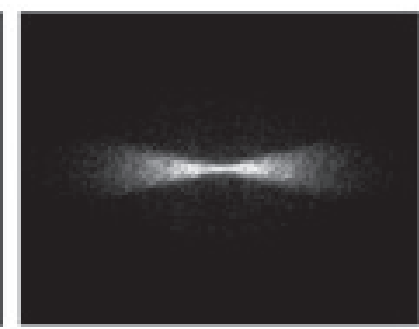

(f) P $1 \mathrm{~mm}$

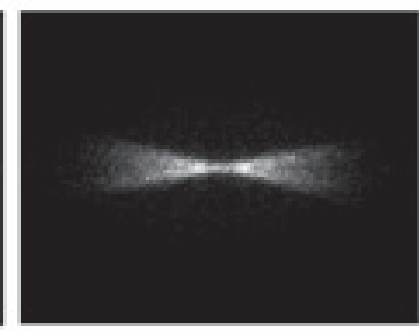

(g) P $2 \mathrm{~mm}$

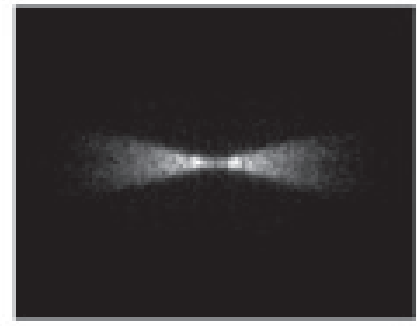

(h) $\mathrm{P} 3 \mathrm{~mm}$

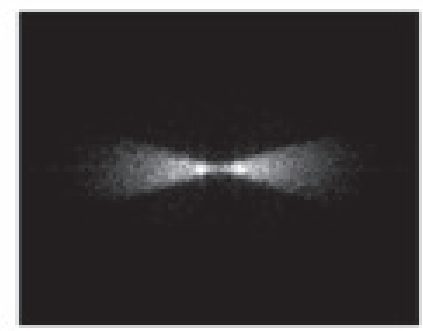

(i) $\mathrm{P} 4 \mathrm{~mm}$

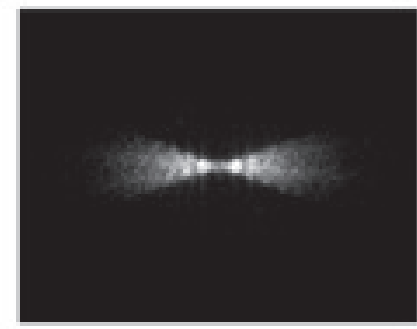

(j) P $5 \mathrm{~mm}$
Fig. 6 Examples of a $2 \mathrm{D}$ power spectrum in each condition.

きくすると, 徐々に複雑かつ細かい画像になるといえる. 三角分布を与えた場合では，ピーク值が大きくなるに つれて低周波域での偏りが見られるようになり, 高周波 域への広がりが減少している. また方向性を示す扇形も 大きな角度を示すようになっている，したがって，ピー ク值を大きくすると, 徐々にテクスチャの左右への振れ が大きな粗い画像になる. 


\section{4 フラクタル解析}

次の $2 つ の$ 性質をもつパターンの集合がフラクタルパ ターンとされる [6].

（1）伝統的な方法では記述が困難な複雑さをもつ.

(2) パターンの部分が全体と相似な構造をもつ.

このうち(2)の自己相似性を, 統計的なものにまで拡張 し，統計的自己相似性を用いることで，自然界における 四形の複雑さを定量化することができる。 パターンの複 雑さの度合いは, 上記(1) と（2）とが相互に関係し，自己 相似性のスケールの変化量がどのように関係するかによ り異なってしまうため, フラクタル次元とよばれる非整 数の次元として定量化される。ここで，1/aに縮小した相 似図形 $\mathrm{n}$ 個で全体が構成される図形のフラクタル次元 $\mathrm{D}$ は，次の式(1)で表される.

$$
D=\frac{\log n}{\log a}
$$

本研究では, 圭目縫い絞りの柄の画像からフラクタル 次元を求めるため, 相似次元を実用的に発展させたボッ クス次元を用いた．ボックス次元 D は, 1 辺の長さが $\mathrm{a}$ の小さな正方形(ボックス)を図形が覆いつくされるよう に並べたときのボックスの個数 $\mathrm{N}(\mathrm{a})$ で表され，以下の式 (2)となる.

$$
\log N(a)=-D \log a+C
$$

ここで $C=\log c$ は定数項である.

ボックスの大きさ $\mathrm{a}$ を変化させながら $\mathrm{N}(\mathrm{a})$ を計数し, すべての計数結果を両対数グラフにプロットする. 式(2) に示した直線的関係が示されたとき，傾き D がボックス (フラクタル)次元となる.

Fig. 7 に正規分布を与えた場合のフラクタル次元の結果 を，Fig. 8 に三角分布を与えた場合の結果をそれぞれ示す. 一般的に, フラクタル次元は複雑な形状ほどその次元 が大きくなる. 圭目縫い絞りのような平面上のテクスチヤ におけるフラクタル次元は, 1 次元と 2 次元の間に相当す る非整数次元となる．また，千分の一程度のわずかな次 元の違いであっても，そのテクスチャの違いはフラクタ ル的に大きな有意差を持つ。

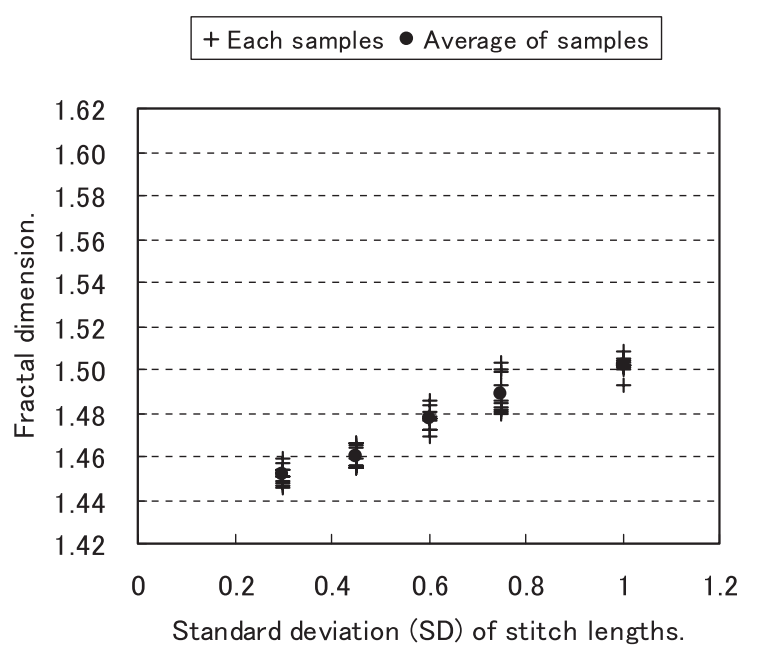

Fig. 7 Relationship between a standard deviation of stitch lengths and a fractal dimension.

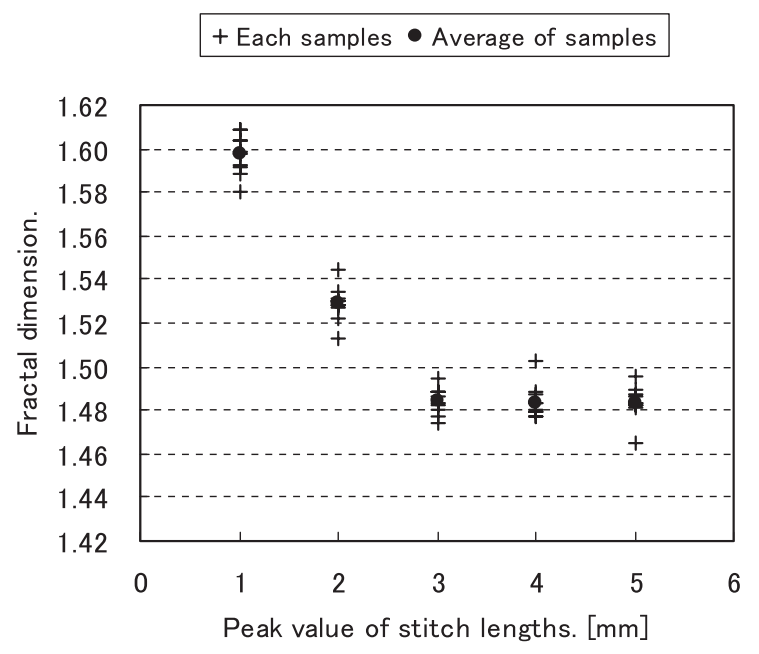

Fig. 8 Relationship between a peak value of stitch lengths and a fractal dimension.

正規分布を与えた場合，標準偏差が大きくなるにつれ てフラクタル次元が大きくなり，柄が複雑になっている. 三角分布を与えた場合では，ピーク值 $3 \mathrm{~mm}$ まではフラ クタル次元が小さくなり，それ以降はフラクタル次元に 大きな変化が見られない。 したがって，ピーク值 $1 \mathrm{~mm}$ か ら $3 \mathrm{~mm}$ まで徐々に単調な柄となり, ピーク值 $3 \mathrm{~mm}, 4 \mathrm{~mm}$, $5 \mathrm{~mm}$ ではあまり柄の複雑さが変化していないことがわかる.

Table 2 Average and standard deviation of stitch lengths in each sample and a fractal dimension.

\begin{tabular}{cccc|cccccc}
\hline & \multicolumn{6}{c|}{ Stitched by Professionals } & \multicolumn{5}{c}{ Stitched by Amateurs } \\
\cline { 2 - 9 } & $\mathrm{A}$ & $\mathrm{B}$ & $\mathrm{C}$ & $\mathrm{D}$ & $\mathrm{E}$ & $\mathrm{F}$ & $\mathrm{G}$ & $\mathrm{H}$ & $\mathrm{I}$ \\
\hline $\begin{array}{c}\text { Average of Stitch Lengths } \\
(\mathrm{mm})\end{array}$ & 2.01 & 2.84 & 2.57 & 3.71 & 3.80 & 2.98 & 2.87 & 3.25 & 3.10 \\
\hline $\begin{array}{c}\text { Standard Deviation (SD) of } \\
\text { Stitch Lengths }\end{array}$ & 0.41 & 0.49 & 0.49 & 0.63 & 0.66 & 0.45 & 0.43 & 0.57 & 0.54 \\
\hline Average of Gray Scales & 23.8 & 19.9 & 20.1 & 21.9 & 21.6 & 19.0 & 19.2 & 19.9 & 20.4 \\
\hline Fractal Dimension & 1.663 & 1.542 & 1.569 & 1.511 & 1.498 & 1.537 & 1.562 & 1.512 & 1.529 \\
\hline
\end{tabular}




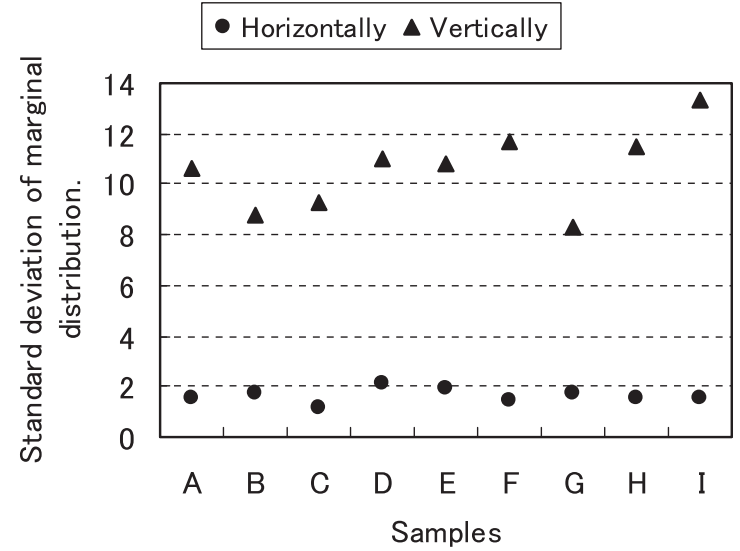

Fig. 9 Standard deviation of a marginal distribution on each sample.

\section{5 実際の絞り柄}

今回の評価方法によって, 圭目縫い絞りの柄の違いを 判別できることがわかった. したがって，これらの方法 のうち, 周辺分布，パワースペクトルおよびフラクタル 次元を用いて害際の圭目縫い絞りの柄の評価を行った.

これらの方法では画像の色階調や濃淡の違いにより算 出結果が影響されるため, 検討には実際の絞り柄の針目 間隔を用いてシミュレーションによって求めた柄とした 用いた針目間隔は，これまでの研究[1]で作成した熟練者 3 名，素人 6 名による試料である。な挹，熟練者の 3 名は， 有松・鳴海地方において 50 年以上にわたり圭目縫い絞り の製作を行っている職人である. また，熟練者の試料で は, 前後の平縫い行における針目間隔の相関があまり見 られず，各行の平縫いが独立して行われていることがわ かっている.

Table 2 に各試料の針目間隔の平均值および標準偏差と 色階調の平均值, フラクタル次元をまとめて示す. Fig. 9 に各試料の周辺分布を，Fig. 10 にパワースペクトルをそ れぞれ示す.

周辺分布について, 熟練者, 素人共に全ての試料にお いて水平方向より垂直方向が大きく, 柄が主に垂直方向 であることがわかった．また，色階調の平均值および水 平方向の標準偏差は, 試料毎にばらつきがあるものの, 熟練者, 素人共にほほ同じ程度の值を示した. 垂直方向 の色階調の標準偏差については, 熟練者の柄は試料 $\mathrm{G}$ を 除いた素人に比べて, 小さい值を示した.

フラクタル次元について, 熟練者の柄は, 周辺分布と 同様に試料 $\mathrm{G}$ を除いた素人に比べて，同じかそれ以上の 值を示した.

また，パワースペクトルについては，全ての試料で低 周波域での強い周期性と高周波域までの半径方向の分布 の広がりが見られた. 特に, 熟練者の柄では, 素人に比 べより高周波までの広がりが見られるが, 中周波域から 高周波にかけての特定の周期性が弱く, また, テクスチャ の方向を示す円弧方向の幅も狭い.

これらの結果から, 熟練者の柄は素人の柄と比較して,

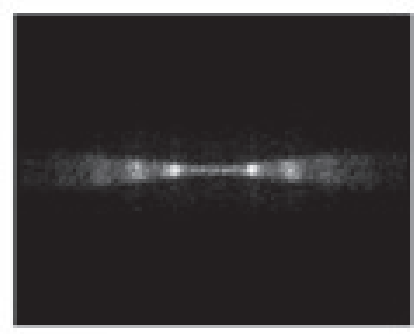

(a) Sample A

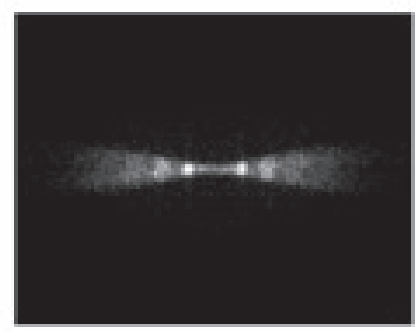

(b) Sample B

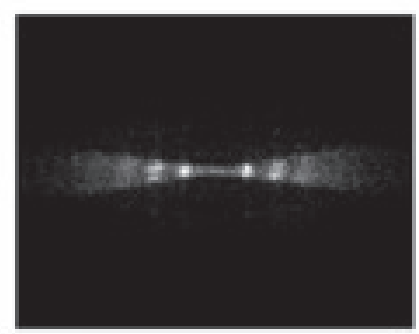

(c) Sample C

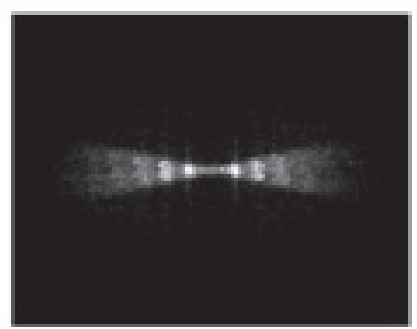

(d) Sample D

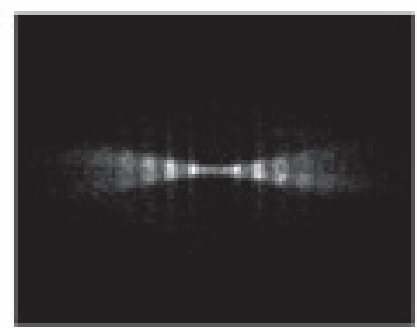

(e) Sample E

Fig. 10 2D power spectrum of each sample.

柄全体の方向が垂直方向を示し, 色階調のばらつきも少 なく細かい複雑な柄である。これは熟練者が素人に比べ, 針目間隔の平均值が小さく，そのばらつきも小さい平縫 いを各行で独立して行っているためと考えられる.

\section{4. 結 言}

本研究では圭目縫い絞りの柄を定量的な特徵量で評価 
し, 次の結果を得た。

1）針目間隔に平均值の等しい正規分布を与えた場合, 標準偏差が大きくなるにつれて, 柄の分岐の数, 途 切れ数の数および周辺分布での色階調の平均值と各 方向の標準偏差が増加し, フラクタル次元の值も大 きくなる．また，パワースペクトルでは，標準偏差 が大きくなるにつれて，周期性が見られなくなり， 高周波域への広がりが強い, 細かい画像になる。し たがって，標準偏差が大きくなるにつれて，垂直方 向に単調で粗い柄から複雑で細かい柄になる.

2）針目間隔に一定の範囲で三角分布を与えた場合, ピー ク值が大きくなるにつれて, 柄の分岐の数, 途切れ 数の数が少なくなり, フラクタル次元の值は小さく なる. また, 周辺分布は平均值と水平, 垂直方向共 に減少からわずかに増加する傾向へとピーク值によ り変化する. パワースペクトルでの評価では, ピー ク值が大きくなるにつれて, 高周波域への広がりが 弱く, テクスチャ方向の広がりが大きい, 振れの大 きな粗い画像になる. したがって, ピーク值が大き くなるにつれて, 細かい柄から大柄であまり複雑で はない粗い柄になる.

3）実際の絞り柄では, 熟練者の柄は素人に比べて垂直 方向の色階調のばらつきが小さく, 方向性を保った 細かい複雑な柄である。

本研究では, 圭目縫い絞りの柄の違いを画像処理手法 による特徵量を用いて客観的評価を行った. 今後. 官能
検査や嗜好検査と組み合わせ, 本研究で用いた特徵量に 対し．評価の閾值や基準值を設けることにより，定量的 な柄の評価が可能であると考える。

\section{謝 辞}

本研究は, 平成 19,20 年度科学研究費補助金(基盤研 究 (C) 19500627)を受けて行われた.

本研究を遂行するにあたり, 画像評価のソフトウェア をご提供下さいました岐阜県製品技術研究所の遠藤善道 氏に感謝いたします。

\section{References}

1. T. Uchida, M. Okamura, A. A. Merati, and Y. Uchita, The $8^{\text {th }}$ ASIAN TEXTILE CONFERENCE, 60 (2005).

2. T. Uchida and M. Okamura, Sen'i Gakkaishi, 63, 218-222 (2007).

3. H. Ando, "Nihon No Shibori Giho", Japan Broadcast Pub., p.89-93 (1992).

4. N. Otsu, T. Kurita, and I. Sekita, "Pattern Ninshiki", Asakura Pub., p.109-123 (1996).

5. H. Tamura, "Computer Gazosyori", Ohmsha, p.214-224 (2002).

6. K. Ozawa, "Pattern Joho Sugaku”, Morikita Pub., p158176 (1999). 